\title{
Transfiguring Indian Agrarian Warehousing Sector with Smart Engineering, Managerial \& Environmental Approaches
}

\author{
Murari Lal Gaur ${ }^{1}$, Shreya Gaur ${ }^{2}$ \\ Professor (Soil \& Water Engg), Dept of Meteorology \& Agril Engg, Anand Agril University, Anand Gujarat, India ${ }^{1}$ \\ Ex Graduate (B.E. Environmental Engg) Govt Engg College (Gujarat Technological University) Surat Gujarat, India ${ }^{2}$
}

\begin{abstract}
The storage and marketing facilities in agricultural sector have imperative linkages, which in turn, cares farmers \& traders to gain more from their agricultural trade. Providing appropriate storage and value adding facilities for food grains/fruits/vegetables/fisheries/poultries/other-farm-produces is emerging as a giant issue for farm engineers, managers, environmentalists, growers, buyers and also the policy planners. Apart from ensuring grading, cleaning and packaging facilities at farm gate; the timely bringing of agricultural products to market, happens to be a vital \& sensitive issue, which invites serious concern towards good governance and effectual strategic interventions on several key aspects. It includes storage, material handling, logistic, marketing infrastructure, communications, smart information, and many environmental considerations; to fetch best possible and balanced profits for growers, suppliers, and buyers with reduced risks \& uncertainties. Realizing vast production potential of massive crops \& commodities, and being top ranker in world, Indian agriculture has arrived at cross roads, where above described anxieties have gained very high impetus to indorse smarter and profitable cultivation/trading. At this juncture, agrarian warehousing is emerging as a subtle \& imperative linkage, to support farmers \& traders for securing optimum connectivity among storage and marketing facets of their trade/business. Present paper is focused towards plethora of such issues, which are reviewed, realized and researched to retrieve realistic inferences on strengths, weaknesses and futuristic potential for enriching agrarian warehousing sector in the country. Comprehensive sets of secondary data/observations are placid \& analysed, offering valued food for thought for desirable schedules/plans from engineering, managerial, environmental, market, and policy points of concerns. It encompasses updated information \& inferences on prevailing status \& types of agrarian warehouses, their shortcomings/potentials/opportunities with probable discretionary rectifications/ modifications. It also touches the role of innovative enviro-friendly technological options (green materials during construction, greener supply chains, energy savings, other environmental dimensions) during construction, operation \& maintenance of warehouses \& logistic essentials, to achieve superlative transformations of Indian warehousing \& marketing sector.
\end{abstract}

Keywords: Warehouses, Cold Storage, Policy, Negotiable Warehouse Receipts, Logistic

\section{INTRODUCTION}

Bringing and linking agriculture to the market is projected as one of the most desired intrusion under varied resentments across different regions of agriculturally dominated countries. In the past 50 years, Indian agriculture has undergone a major transformation, from 'dependence on food aid' to becoming a 'consistent net food exporter'. The far-reaching changes in domestic \& global markets are projecting bigger opportunities both for farmers and agribusiness entrepreneurs (Gulati and Ganguly, 2010). Looking into its inherent strengths \& potential and also the demand-supply scenario (ASSOCHAM,2016), agriculture is well set to get recognized as profitable business intervention, rather than age old art of producing food grains to cater the people's routine feeding needs. Under prevailing adverse situation (population explosion, climate change/uncertainties) it is possible only and only when farmers got actively linked with market $\&$ associated earnings, where they can fetch their due profits. India has tremendous inherent strength in this regard, producing world's highest production volumes and being globally $1^{\text {st }}$ ranked nation in regards to products like milk, rice, fruits, and vegetables. The level of produced volumes of many other agricultural commodities too remained very high, foretelling India among top 3 ranks at world level. Indian farmers offer $17 \%$ of whole world's milk production, > 250 million metric tons (MMT) food grains, >165 MMTs vegetables, and > 80 MMTs fruits, together with sharply ascending volumes of many other innovative products like flowers, fishes, eggs etc in recent time. With these the ultimate economics of agrarian sector in country is marching ahead with high projectiles (Hazell and Haggablade, 1991; GOI, 2013). Existence of plentiful agrarian warehouses is emerging as one of the most vital and sensitive subjects for India, where agriculture continues to be a deep-seated tool to accomplish sustainable growth and poverty diminution (Birthal, et al., 2014; Bathla, 2014). Yet the pecuniary constraints in regards to warehousing, remain 


\section{International Advanced Research Journal in Science, Engineering and Technology}

Vol. 5, Issue 11, November 2018

highly persistent as they are pricey, inequitably distributed, and sternly frontier with small farmers or trade holder's ability to contend. Country is having only $2 \%$ of world geographical area, but encompasses $16 \%$ of world population, and has agrarian people to the tune of 65 crores, covering more than 6 lakhs villages under 127 agro climatic zones, where agricultural activities are largely carried out by poor farmers on 121 million operational holdings, $80 \%$ of which are marginal \& small having less than 2 ha land holdings (Gaur, 2015).

In spite of all such exceptional end deliveries with extreme production potential, an average Indian farmer still remains deprived, socio-economically disadvantaged, and far away from grown economy and markets. Majority of his due benefits/income gets either dampened or percolated to middlemen or vanished on farm itself, because of poor storage/logistic/market element. Majority of farmers and small agricultural traders operates their business, under extreme unfavourable circumstances, where neither the climate nor the financial sphere remains compassionate towards them; rather it tenders high magnitude of uncertainties and constraints. Owing to towering inefficiencies in warehousing, marketing, and supply chain, often they feel themselves handicapped and so suffer invariably, with heavy losses of income \& commodities due to improper storage/transportation/market facilities. Only due to insufficient storage and logistics, around 20 to $30 \%$ of total food grain harvest is estimated to be wasted, as on an average each grain bag is often handled at least 5 to 6 times before it is finally opened for processing. Also due to lack of proper cold storage facilities, a cumulative loss of about 550 million Indian rupees is projected in recent time (ASSOCHAM, 2014). Prevailing scenario towards agrarian warehousing is becoming more multifarious owing to huge gap between demand $\&$ supply of logistic services, asking an effective integration of logistics with warehousing \& marketing. It is of utmost importance as more recently country is emerged as leading producer of exportable variety products like wheat, cotton, groundnut, lentils, sesame seed, sorghum, millet, jute, spices, sugarcane, cashew nut, silk worm, tea, potatoes, onions, garlic, tropical gingers, cauliflower, peas, cabbage, pumpkin, squash/gourds, bananas, mango, guava, and enormous flowers. Owing to strengths cited above country has vast potential, where warehousing and marketing aspects could be easily made smart (Gaur, 2015) and result producing. Environmental engineering principles happens to be another big opportunity at this crucial stage, where just substituting some of the prevailing materials, mechanisms, modalities, methods; with their smarter technological versions (ICT \& IT, digital, environmentally responsive) at varied stages of warehousing policy planning/executions/operations/maintenances could highly decline emissions \& overall environmental adverse impacts (Rai et al., 2011). Present paper is focused in and around to this crucial issue, where plethora of emerging issues are reviewed \& researched to arrive at few important inferences in regards to relevant strengths, weaknesses and futuristic potential for enriching agricultural warehousing \& marketing sector of country.

\section{METHODOLOGICAL DESCRIPTION}

A vast magnitude of literature and data mining is performed to assess the central issue of this research leitmotif, starting from 'farmer's field' up to 'marketing yard' or even the point of time when real cash income is virtually seen in hands of the agricultural grower/trader. The historical ingredients of Indian agriculture and its periodic updates with in-depth analysis of all relevant sub sectors is performed by visualizing, analysing, and interrelating the observations and remarks of enormous professional experts, researchers, and R\&D agencies. The set of available information and other secondary data sets were accordingly utilized herein. A vast volume of such data and information is excavated, moreover only few bits are being incorporated herein, owing to paucity of space and scope of this particular research paper. Secondary data on basics of agricultural policies with periodic reforms, generalized warehousing policies and actions, major agencies to deal with these kinds of interventions, ways to arrive on updated status of farmer and his agriculture-based issues are compiled and compared. Leading institutions, schemes, projects, missions, plethora of problems \& issues as relieved/released from time to time are too observed and correlated there upon, to offer many meaningful inferences of practical significance. Attempts are made to follow, standard protocols and reliable sources while deriving/extracting such observations and their treatments at later stages. Observed secondary data, were made with a level of quality \& quantity, where it can be said/designated a most updated and reliable kind of information bits.

A. Prevailing Features of Warehousing: Whereas going across various kinds of agricultural warehouses in the country (GOI, 2011), and assessing their functional utilities, basically a warehouse can be easily defined as "a place used for the storage or accumulation of goods". The exact function of storage can be carried out successfully, provided an appropriate warehouse is opted for storing the goods in good condition. Some time, warehousing is also demarcated as "assumption of responsibility for the storage of goods throughout the year and releasing them as and when they are needed and thus creating time utility". Warehousing has enormous importance in development of agricultural trade, commerce, and net profits from real ground farming. In real sense, it refers to the "holding and preservation of goods until they are dispatched to the consumers". In accordance to prevailing situation in India, there exists a 'time gap' between the production and consumption of products, which could be easily bridged with a good warehousing at micro scales. In principal, any good warehousing is often judged by comparing delivery of five specific functions, namely; storage, price-stabilization, risk-bearing, financing, and gradin/packing. If these functions are attained satisfactorily, then only benefits from warehouses are assured. Overall warehousing gives many clues \& guidelines towards cost break 


\section{International Advanced Research Journal in Science, Engineering and Technology}

Vol. 5, Issue 11, November 2018

ups. A generalized thumb rule-based relationship between physical circulation of agricultural commodities and relevant wastages along with the wider variabilities of region wise distribution of warehouses in the country is illustrated in Fig. 1 which is self-explanatory to depict the levels of disparities and adversities of prevailing warehousing domain in the country.
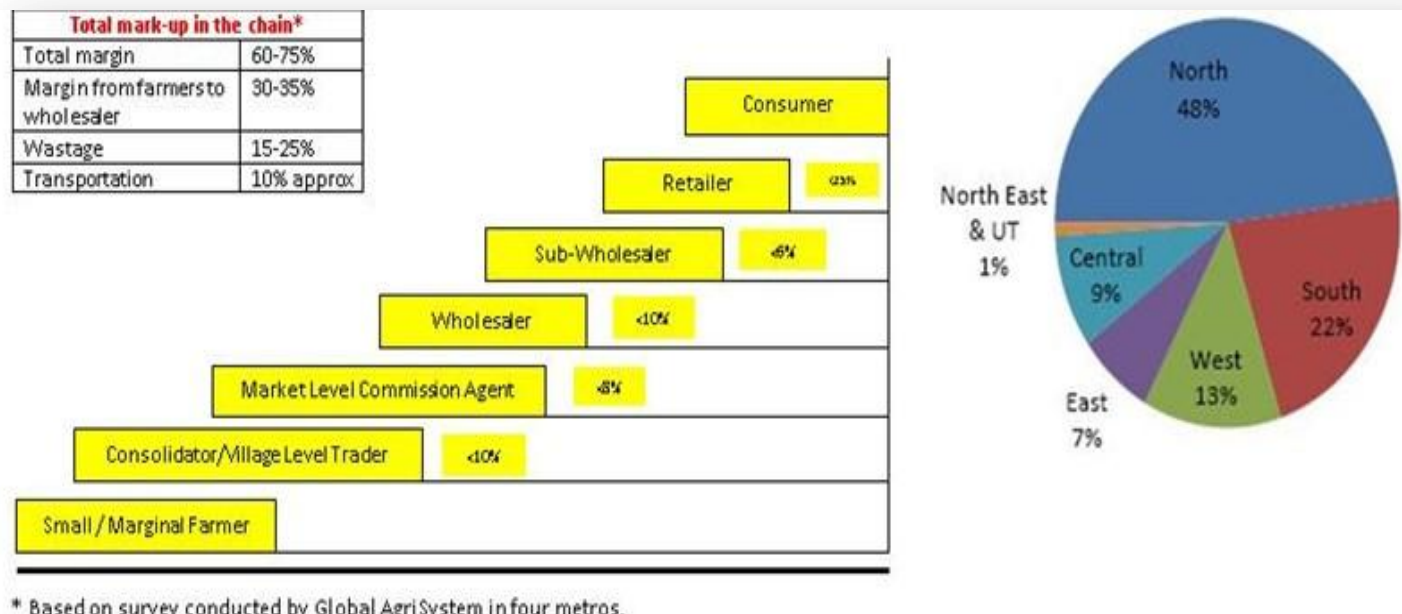

Fig. 1 Few basic and common disparities of Indian water housing sector

With a view to upsurge the involvement of private sector and development \& directive of warehousing industry, Government of India introduced 'The Warehousing (Development and Regulation) Act', with a major focus to establish a regulated environment for issuance of Negotiable Warehouse Receipt (NWR) under Warehousing Development and Regulatory Authority (WDRA) which was constituted in October 2010. There remained several bottlenecks, because of which at least $20-30 \%$ of the total food grain harvest is wasted due to inadequate storage capacity, regional imbalance in warehouses, lack of adequate scientific storage and inefficient logistic management in the country. It is said that each grain bag is handled at least six times before it is finally opened for processing which leads to higher storage \& transportation charges and also increases to wastage of food grain during transit $\&$ handling. With all these issues, much needs to be done to physique additional storage capacity with cost \& environmental considerations, renovating existing warehouses and implementing an ICT \& IT based smart and robust system of NWR to make available added funds to farm producers and simultaneously provide security to the lenders. The need of hour is to enhance the regionally balanced erection of modern warehouses keeping in view the fusion of high-tech materials, methods and management, and following due protocols of environmental laws and principles. Some of the other necessities are equal importance to get focused on wider agricultural commodities and developing a network or clusters of warehouses in a fashion where more warehouses issues NWRs for growers.

B. Predominant Form of Warehouses: By looking into the complete spectrum of agricultural warehousing sector in India (Chand, 2012), the existing warehouses can be broadly categorized in four specific types,

1. Private Warehouses: They are owned and operated by big manufacturers/ merchants to fulfil their own storage needs. The goods manufactured or purchased by the owner of warehouses have a limited value or utility as businessmen in general cannot make use of them because of the heavy investment required in the construction of a warehouse, some big business firms which need large storage capacity on a regular basis and who can afford money, construct and maintain their private warehouses.

2. Public Warehouses: A public warehouse is a specialized business establishment that provides storage facilities to the general public for a certain charge. It may be owned and operated by an individual or a cooperative society, but has to work under a license from the government in accordance with the prescribed rules and regulations.

3. Public Warehouses: These are very important in marketing of agricultural products specifically in cooperative sector, sometime known as duty-paid warehouse, being very useful to business community. They provide storage facilities to small manufacturers and traders at low cost, and are well constructed/guarded round the clock to ensure safe custody of goods, and usually located near junctions of railways, highways and waterways.

4. Bonded Warehouses: These are licensed by government to accept imported goods for storage until the payment of custom duty, and are often located near the ports. These warehouses are either operated by government or work under control of custom authorities, having supportive provision for importers \& exporters, who can withdraw goods in instalments by paying customs duty proportionately. 


\section{International Advanced Research Journal in Science, Engineering and Technology}

Vol. 5, Issue 11, November 2018

C. Dynamic Roles of Warehousing: Methodological reviewing has well established that the warehousing use to be the backbone for developing any trade or commerce (GOI, 2011), being more valid for agrarian sector, owing to sharp rise in agro-processing and agri-business industry. Agrarian warehousing always looks to play a very decisive role in strengthening agricultural supply chain, ensuring food security, price stabilization, and net income of farmers/traders. It also solves the problems of glut and scarcity by maintaining uninterrupted supply of agricultural commodities in all season. Under the changed era, the function of a warehouse does not remain confined only up to a storage or as a godown, rather it needs to incorporates manifold functions namely, receiving, inspection, repacking, put away, storage, order picking/selection, quality grading, packing, shifting, cross docking, and replenishing. These functions remained specific for a given situation in regards to either the commodity to be taken/dealt or the exact type/category of existing warehouses.

D. Key Warehousing Agencies: Available data and searching methods show that in India there are many agencies (government and non-government) that tackles the warehousing activities. Country has three major agencies namely Food Corporation of India (FCI), Central Ware Housing Corporation (CWC), and State Ware houses corporations (SWCs), which are often remained engaged in building and maintaining large scale storage/ warehousing capacity, with specific policies, as given below,

- FCI has objective of fair distribution of food grains and to bring about stability in the prices, with a provision of scientific storage for vast volumes of food grains/other commodities and also to provide easy physical access in remote \& inaccessible areas, with dense network of strategically located storage depots. These depots include silos, godowns and an indigenous method developed by them, called Cover and Plinth (CAP), where storage of food grains is done in open space with adequate precautions for rats and rains.

- CWC was earmarked another premier warehousing agency, being one of the biggest public warehouse operators in the country offering logistics services dealing with more than 500 warehouses across the country with a storage capacity of at least 11 MMTs. Apart from storage \& handling, it also offers services in area of clearing/forwarding, handling \& transportation, procurement/distribution, disinfestations/fumigation/other ancillary services.

- SWCs are storages facilities as detected set up in different Indian states, giving state-based nomenclature. They usually operate keeping districts as central unit, ensuring that total share capital of SWCs is contributed equally by concerned State Governments and the CWC.

\section{SALIENT UPSHOTS AND DELIBERATIONS}

Based upon plethora of observations and reviews from results and secondary source information, efforts were made by authors to deeply traverse the issues and portraying a suitable canvas being perceptive to target the important gaps and their cause-effect relationships. The focused inferences keeping small and marginal farmers of India as target, are synthesized and being offered herein under broad categories to reflect the warehousing-based interventions in both the agrarian as well as environmental domain. Some of the key information and logical discussions in this regard are presented below, to touch and realize the constraints and possible ways for Indian conditions.

A. Echelon of Warehousing Competitiveness: In the complete logistics value chain, warehousing forms a very important link. Warehousing, which forms $20 \%$ of the total logistics market, was traditionally used as god owns to store goods from the time of production till the time of consumption. Over time and with the changing role of the sector, traditional warehouses have transformed to collection and storage points, where raw material, intermediate and manufactured goods are collected, assorted, stored and distributed to the point of consumption/sale. The warehousing market in India is expected to grow at a rate of 35 to $40 \%$ annually, displaying high potential for growth over the next few years. Currently, the sector is highly fragmented with small players holding small units distributed across states with many challenges. Table 1, depicts some of the benchmark digits in terms of physical and financial targets and achievement as found across different Five Years Plans (FYP) in India. special purposes.

B. Emerging Challenges and Issues: The level of infrastructure and financial organization, very deeply influences the net outputs, which is found truer in agricultural sector in accordance to many assessments (Binswanger, et al., 1993; Roy and Pal, 2001). Prevailing policies \& reforms as undertaken have not yielded due outputs matching with projected results owing to sectoral short comings like,

- Prevailing policies could not fully address the issue of insufficient storage infrastructure. Existing storage potential of leading agencies like FCI, CWC, SWC's etc are extremely short and unevenly distributed (Table-1). Policies are inappropriate to ensure farmers' market linkages (both backward \& forward), private trade, poor invest in marketing infrastructure due to excessive regulatory framework/dominances. 


\section{International Advanced Research Journal in Science, Engineering and Technology}

Vol. 5, Issue 11, November 2018

- Very little attention is being paid on cold chains (hardly 5400 cold storage facilities with a combined capacity of 23.66 MMT) which are un organized, being operated far below capacity. Estimated potential remains as high as 8 billion USD (ASSOCHAM 2014). Current policies favor to utilize majority of existing cold storage facilities for a single commodity (e.g. potatoes) and that too being confined to limited states/locations. As per one such estimate (GOI, 2014) the distribution of present capacities (MMTs) includes Potato (9.282), multi-purpose(0.763), Fruits \& Vegetables (0.107), Meat ( 0.009), Fish( 0.073), Meat \& Fish (0.015), Milk \& Dairy Products (0.068), and Others (0.036); which is yet another challenge demanding solutions at regional \& national level (Gaur, 2015).

- Tackling logistic/transport sector on agricultural commodities is another big gap with cast scope. It is interesting to note that of the estimated 25000 vehicles in use, $80 \%$ transport dairy products (wet milk); only 5000 refrigerated transport vehicles are available for all other commodities. If we compare globally, the $\%$ of movement of fruits \& vegetables through cold chain in U.S. is around 80 to $85 \%$, in Thailand 30 to $40 \%$ but in India it is insignificant. Such situation invites deeper sensitivities of planners on policy framework in this regard (Gaur, 2015; Gulati and Ganguli, 2010).

- Even the highest body on warehousing, WDRA feels hurdles to mandatorily regulate all warehouses except those who intend to issue NWRs. Other than cancelling registration of those willingly registered with it, WDRA does not have ample coercive powers to impose penalties against those who are issuing NWRs in violation of WDRA acts.

Table 1. Approved plan expenditure/physical capacity vis-à-vis achievement for erection of godowns under plan scheme of last 6 five years plans of India

\begin{tabular}{|l|l|l|l|l|}
\hline \multirow{2}{*}{ FYP } & \multicolumn{2}{|c|}{ Physical (In Lakhs MT) } & \multicolumn{2}{c|}{ Financial (Rs in Crores) } \\
\cline { 2 - 5 } & Target & Achievements & Target & Achievements \\
\hline VI $^{\text {th }}$ & 28.65 & 24.63 & 156.25 & 180.22 \\
\hline VII $^{\text {th }}$ & 27.30 & 24.84 & 247.50 & 265.42 \\
\hline VIII $^{\text {th }}$ & 5.51 & 4.54 & 103.61 & 113.72 \\
\hline IX $^{\text {th }}$ & 4.54 & 3.96 & 111.40 & 110.61 \\
\hline X $^{\text {th }}$ & 3.62 & 3.67 & 87.61 & 86.62 \\
\hline XI $^{\text {th }}$ & 0.955 & 0.45 & 124.875 & 86.74 \\
\hline
\end{tabular}

Source : FCI (2018)

Table 2 Storage capacity for central pool stocks for the last five years in India

\begin{tabular}{|l|l|l|l|}
\hline \multirow{2}{*}{ As on } & \multicolumn{3}{|c|}{ Overall storage capacity (lakhs metric tons) } \\
\cline { 2 - 4 } & with FCI & with other Agencies & Total \\
\hline $01-04-2011$ & 316.10 & 291.32 & 607.42 \\
\hline $01-04-2012$ & 336.04 & 341.35 & 677.39 \\
\hline $01-04-2013$ & 377.35 & 354.28 & 731.63 \\
\hline $01-04-2014$ & 368.90 & 379.18 & 748.08 \\
\hline $01-04-2015$ & 356.63 & 352.59 & 709.22 \\
\hline $01-04-2016$ & 357.89 & 456.95 & 814.84 \\
\hline $01-04-2017$ & 352.71 & 420.22 & 772.93 \\
\hline $01-04-2018$ & 362.50 & 480.53 & 843.03 \\
\hline
\end{tabular}

Source : FCI (2018)

C. Engineering and Environmental Design Considerations: Environmental design not only considers the building, structural, mechanical, electrical and other constituents of a warehouse system, but equally put attention to care climatic, weather based and other environmental entities like storm water management, drainage, humidity \& moisture, and many other indirect essentials (Meneghetti and Monti, 2014,2015) in efficient environmental design always allowed to maximize the useable area while avoiding and minimizing environmental constraints. Warehouses are now a days critically seen from the angle of environmental justice issue. For example, when we ponder of locally unwanted land uses, we often think of large power plants, puffing single clouds of pollution. But many clouds of pollution from trucks \& tractors traveling to and from warehouses can have equally large impacts on health. These automobiles travel frequently to deliver the produces/goods to warehouses, and further move them from those facilities to customers/markets at variety of time and spaces. This altogether advocates to consider warehouse system in a holistic manner, by coming out of the four walls and giving best possible environmental considerations; while planning, designing or even expanding the prevailing warehousing systems.

Environmentally responsive design using eco-friendly construction materials remains the first and foremost step, to contemplate a truly smart \& modern warehouse; ensuring effectual abilities in terms of energy efficiency, low cost, easy 


\section{International Advanced Research Journal in Science, Engineering and Technology}

Vol. 5, Issue 11, November 2018

operation \& maintenance, weather \& climate resistant, and environmentally welcoming. Engineering \& environmental parameters are thereafter made parts of other constituents inside the warehousing sector; which includes storages, internal \& external movements, inventories, and IT \& ICT enabled trades \& tracks. In a general setting, the supply chains and logistics constitutes the biggest warehousing challenges which needs to be overcome by smart versions of man, machine, management and marketing. Automation with energy efficient smarter \& digital elements has high potential to govern below given major challenges (Tappia et al., 2015; Fichtinger et al., 2015).

- Inventory accuracy to ensure full visibility to avoid/minimize unfulfilled orders and unhappy customers.

- Inventory location to improve efficiencies within warehouse avoiding slows operations \& cost increases

- Ensuring optimized space utilization within available warehouse layout to avoid unnecessary labour.

- Ample \& effective redundant processes like barcode technology for reducing time loss.

- Picking optimization for shipment with system-directed automated routing to pick/ put away, reducing wear and tear on equipment and the workforce.

1. Specified Design Components/Considerations: Special-designed warehouses meeting strict requirements can also provide liquid storage (fuel and non-propellants), flammable and combustible storage, radioactive material storage, hazardous chemical storage, and ammunition storage. Features already now common in warehouse designs are higher bays, sophisticated materials-handling equipment, broadband connectivity access, and more distribution networks. A wide range of storage alternatives, picking alternatives, material handling equipment and software exist to meet the physical and operational requirements of the warehouse. Warehouse spaces must also be flexible to accommodate future operations and storage needs as well as mission changes.

- Building Attributes: Ample utilitarian facilities delivering functional, efficient, safe, and comfortable environment for workers to increase productivity \& control, reduce operating costs, and improve customer service with proper aesthetics, landscaping.

- $\quad$ Categorical Forms of Spaces: storage Space, office space, loading docks, light industrial space, computer centres

- Space Configurations : to meet current \& future needs, facilitate changes in business/agency growth, ,accommodate need for future loading docks, truck space, and parking spaces, addressing material handling technologies, proper roof design using solar aspects, fire protection capacity, adequate circulation paths, higher bays to take advantage of height allowances, optimized configurations ,relating interior and exterior receiving and shipping operations to the process flow of goods, properly separated receiving/shipping to avoid congestion ,other material handling methods.

D. Policy Related Trepidation \& Solution Keys: A deeper analysis of obtainable situations invariably projects that exists in India, showed that the agricultural warehousing has plethora of troubles. Even till now, there remains wider gap and thus lack of unrelenting due investment in warehousing sector. One of the most influential reasons for it is the fact, that private sector initiatives in agricultural warehousing sector remained extremely small \& sporadic, when compared the scenario of warehousing of other industrial sectors. Fuel is added to fire, with associated shortcomings and other important reasons like, (1) available warehousing capacities are inadequately small, (2) Often they are not of good quality and (3) they are located in fragmented manner. In recent past one of the 'Government of India Working Group' on ware housing development $\&$ regulation for the $12^{\text {th }}$ plan period, observed and established the need for formulating a comprehensive post-harvest scheme for the farmers at the national level, because a substantial quantity of food grains (6 - $10 \%$ of total production) are damaged due to moisture, insects, rodents and fungi alone. Some prominently emerging issues in regards to warehousing remains as follows,

- Proportionate efforts/infrastructure/allocation/importance towards agricultural warehouses is extremely diluted and it is almost ignored if one compares it in relation to industrial sectors. Hardly $12-14 \%$ of total warehouse capacity accounts for agricultural commodities, even when warehousing market, is growing at $9 \%$ annually and is expected to cross Rs 35000 Crore market in 2015-16 (ASSOCHAM, 2014).

- Logistic scenarios in regards to agricultural ware housing are not favourable. More than $80 \%$ of agricultural commodities for domestic consumption are transported by road with poor share of rail owing to shortage of rakes, which was reported 6 to $17 \%$ short in 2012 .

- Issues of poor handling \& service at railway terminals are another burning issue.

- The continuous supply of fruits, vegetables and other essential commodities to consumers ensures food security in country. A study by Global AgriSystem of Fruit \& Vegetable supply chain (Patnaik, 2011) in 4 metros (Delhi, Mumbai, Bangalore and Kolkata) revealed that, on an average there are 5-6 intermediaries between the primary producer and consumer.

\section{E. Application Issues of Warehouse Policies}

1. Prevailing Inadequacies: Even if we add other scattered storage options (farmers, or private), in no case total storage capacity exits above 110-120 MMTs, while at prevailing point of time India has already reached to a situation where the total food grain production is more than 250 MMTs. 21 MMTs of wheat and about 40 MMTs of fruits \& 


\section{International Advanced Research Journal in Science, Engineering and Technology}

Vol. 5, Issue 11, November 2018

vegetables is lost between the grower and the consumer due to shortcomings like lack of refrigerated transport, poor roads, improper storage \& marketing avenues. If growth in agricultural warehousing, storage \& transportation facilities fails to match above cited realistic demands, this problem is likely to be further accentuate, because the development and modernization of agrarian sector is always projected to deliver elevated volumes of commodities. Existing warehousing capacities as cited above are not only in-sufficient but in truer sense their spatial spread more often, reflects a cosmic heterogeneity as far as their want is measured over space \& time. It becomes evident from an example, when we look into the national spectrum of available storage space say with FCI. It is quite flagrant that so called storage space remains strenuous mainly in the pouring nucleus located in Northern Zone (about $65 \%$ of total) followed by Southern Zone (15\%), Western Zone (12\%), Eastern Zone (7 \%) and North Eastern Zone (1\%) of country. Around $69 \%$ of cargo space is resolute in 8 major procuring states i.e. Punjab, Haryana, Uttar Pradesh, Andhra Pradesh, Telanagana, Madhya Pradesh and Chhatisgarh, while only about $7 \%$ exists in 4 newly emerging procuring states of Bihar, Odisha, Jharkhand and West Bengal. Cluster of ware houses \& marketing facilities in an around farmers field, small producers/traders is a crucial need of present time, for which there remains vast opportunities. It could extend benefit in two ways, firstly generating warehouse at farmers door step to safeguard their time, net come and profit margins; and secondly to accommodate about additional 40-50 MMT of agricultural commodity by 2020 , which are expected/projected from Indian farms owing to technological applications thereupon.

2. Innovative Efforts: There are plenty of new innovative efforts for promoting warehousing and logistic related improvement in agricultural sector. Discussion on all these is beyond scope here, moreover one extremely imperative effort was the concept of Negotiable Ware House Receipts (NWRs), which has been deeply and effectually applied in India to facelift the warehousing sector, making it as a platform to offer multiple benefits to farmers, traders, and agricultural sector as a whole. These benefits encompass many valuable things like, increased liquidity in rural areas, encouragement of scientific warehousing of goods, lowering cost of financing, shorter and more efficient supply chains, enhanced rewards for grading and quality, and a better price risk management for majority of situations during farming as well as trading.

3. Negotiable Warehouse Receipts (NWR) as a New Dimension: Concept of NWR is being recommended as one of the most successful intervention in agricultural marketing, as NWR documents are issued by warehouses to depositors against the commodities deposited in the warehouses, for which the warehouse remains the bailee. It could be either non-negotiable or negotiable both, and often remains transferable by simple endorsement /signature. NWRs are transferred by endorsement and delivery; i.e., either the original depositor or the holder in due course (transferee) can claim the commodities from the warehouse. These can be traded, sold, swapped or used as collateral to support borrowing. Basically, the term NWR is most appropriately defined under Warehousing (Development and Regulation) Act, 2007. In spite of it, the Indian agriculture is almost in the grip of a debt trap, where overall market failure is resulting from regulation point of view. Several studies have revealed a strong recommendation for negotiable ware house receipt (NWR) case for market reforms, by encompassing all critically emerged issues like, current policy \& regulatory frameworks which impede growth, need for a broader legal framework to facilitate growth of NWR, and integration of national spot exchanges with commodity exchanges etc. So framed new NWR system could offer several benefits for trading by farmers like,(i) easing storing of their produce in nearest registered warehouse, (ii) encouraging them to take NWR to nearest physical market ('spot market' or virtual market i.e. 'spot exchange') and selling it to a trader or vice-versa, and (iii) ensuring more credibility to NWRs, facilitating paper based direct trading by farmers adopting grading of commodities \& scientific storage in nearby accredited warehouse (i.e. 3rd party). A global analysis on success and failures of such NWRs based applications have shown comparative attractiveness of field $\&$ public warehousing, as a function of the borrower's logistics needs and the external environment. No more than 3 levels of headings should be used. A functional flow diagram (Fig. 2) of NWR concept reflects its various ingredients, which have enormous plus points, moreover, the truer ground verifications of NWRs have shown its own shortcomings as given below,

- $\quad$ Crop loan interest subvention scheme to improvise the NWRs in order to discourage distress sell by farmers, gave many impediments during its active implementation. Only those farmers who have obtained crop loan are entitled for post-harvest loan on NWRs, that too for a period of another 6 months only, releasing adverse impacts on small \& marginal farmers.

- $\quad$ Bank use different collateral manager for different cases of NWRs based financing. Problem could be reduced if a group of 5 or 6 NWR based finance be given to a common manager with specific training for NWRs.

- $\quad$ Lack of publicity of scheme, active monitoring of pledge financing on NWRs by banks, and difficulty faced by farmers while making payment of post-harvest loan to banks, are some of the other shortcomings. 


\section{International Advanced Research Journal in Science, Engineering and Technology}

Vol. 5, Issue 11, November 2018

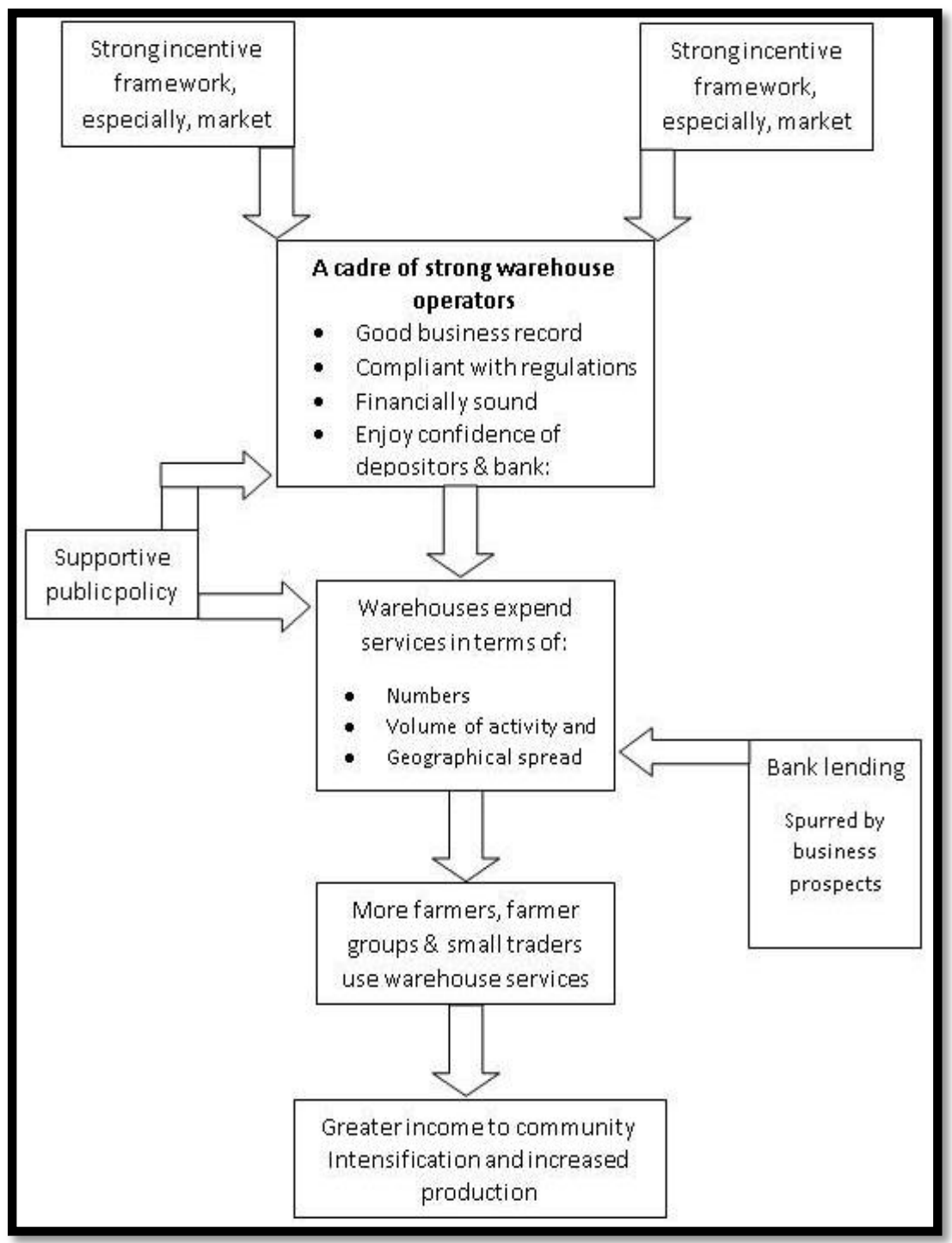

Fig. 2. Broader conceptual frame work of ware house receipts system

F. Futuristic Elucidations from Famer's Perspectives: Farmers under Indian conditions often need a timely credit which is habitually provided by a trader either by holding the farmer produces as collateral; or in kind i.e. in form of inputs (seeds, fertilizers, supplements etc). Situation becomes grimmer for small and poor farmers when storage facility is either not available with them, or it is owned by the trader, who never encourage such needy farmer to get credit from other sources. It gives 3 major cases,

1. Either trader sells farmers produce \& deducts principal \& interest, (price received by farmers is not competitively discovered \& thus forcing farmer to sell through trader only)

2. Distress sales by farmers to square off debts soon after harvesting, even loosing capital.

3. Improper support service providers like, extension, market intelligence, credit, inputs.

Multiple roles performed by traders allow them to exploit farmer, who finds himself in a debt trap (Chand, 2012). Only viable solution in this regard looks to be efficient \& better regulated (structurally \& environmentally) warehouses located nearby farmers and thus facilitating a supply chain and good alternatives with growers to fetch best possible benefits from their crops/commodities. Further promoting warehousing with intensive applications of NWRs is going to greatly benefit the small and marginal farmers. If warehousing sector is improved it is well established by the published results and practical exposures and experiences of many nations that it is a win-win situation both for growers, traders and consumers who so ever deals with agricultural crops and commodities. Some of the far-sighted benefits to an average small and marginal famer are,

- Better linking of farmers to markets \& strengthening of value chains, to improve market access \& trade, and also easy up challenges for most agricultural commodities.

- Positive agri-business with ensured profit to small \& marginal producers. 


\section{International Advanced Research Journal in Science, Engineering and Technology}

Vol. 5, Issue 11, November 2018

- Training and awareness for yielding relevant quality HR for warehousing

- Additional storage capacity to the tune of at least 35 MMT giving better extent of agri-business options at national and regional scales.

- Downsized post-harvest losses, additional support to improve infrastructure, information technology, post-harvest handling, easy access to finance via NWRS, improved rural investment climate, skills development, risk management, and transparency in markets.

- Traditional knowledge \& wisdom of farmers could be better valued \& translated to achieve location specific climate-smart post-harvests, functioning \& maintenance of the physical storage structures, market information/transport options, collective leanings, reduced asymmetry in access to key commodity information \& efficient marketing, enabling farmers to negotiate better prices, free trade being important part of this value chain.

\section{SUMMARY AND CONCLUSION}

There exists a vast gap in demand and supply of agricultural warehousing facilities and infrastructure across the nation, which invites a sharp and focused attention to harness the vast strengths and potential of agricultural crops and commodities being delivered by hard working farmers making world records even under enormous constraints. If we put down the issue of prevailing shortage, even than it is another astonished fact to realize that for world's premier agrarian nation and agrarian economy like India, about $80 \%$ handling and warehousing facilities are still not fully automated or even mechanized. Traditional manual methods for loading, unloading and handling of food grains and other commodities are still common. However, the warehouses which are mechanized have just forklifts or hydraulic hand pallet trucks. The observation and statistics clearly indicate that there is an acute shortage of organized and good quality warehousing and storage infrastructure in the country. Warehousing in India has been linked to food security and agricultural growth Warehousing is now seen as an integral part of the supply chain where goods are not only stored for safekeeping, but also where other value processes are implemented, thereby minimizing wastage and costs. Warehousing in agriculture is part of the larger agricultural ecosystem. Just like agriculture, the warehousing market is local, unorganized, and fragmented. National standards have not yet been uniformly adopted or mandated, and the quality of warehousing and the contractual obligations that Warehouse Service Providers (WSPs) enter into, vary widely across regions. Under modernized agriculture the intended role of warehouses has been amplified due to wider product range, emphasis on shorter lead times and constant changes in customer demand with varied quality and quantity fronts. The increased demands force agricultural traders or farmers to improve upon their storage operations for better service level with decreased costs. Transportation and agricultural logistic factors are being appeared equally important and most relevant factors in this regard, where they deeply influence the overall warehousing capability and competence in various regions of the country. The available options in terms of new technologies, logistics and supply chain management, IT \& ICT based handling, electronic linkages of warehouses and markets, organized operations \& management, collaborative efforts among all stakeholders (Government agencies, policy makers, entrepreneurs, investors; logistics services providers, manufacturers, farmers and sellers) are the potential prospects in this regard.

Key issues which needs to be realized and rectified are, government policy for warehousing, public-private partnership in Warehousing development, financing \& modernization of warehousing, scale and quality of warehousing infrastructure, various regional \& national constraints and Impediments in setting up of new warehouses, integration of warehouses with complete supply chain, better strategies to leverage modern technology, studying key trends and future plans, availability and access to funding, capacity building and operational efficiency of warehouses, higher investment opportunities, improved R\&D and sector investments, and creating smart and sensitive human resources. The food for thought offered in present paper happens to be a preliminary contemplation of author which might have some deficiencies and in appropriateness. Moreover, the findings obtained herein present alarming indications to consider agricultural warehousing very sensitively and putting converged efforts to facilitate better net profits for agricultural farmers and traders. Managerial issues of Indian agrarian warehousing sector inevitably need a comprehensive scenario analysis from not only physical infrastructural point of views but also from environmental understandings \& perspectives. Smarter upright strategy, viable competitiveness reforms, managerial \& environmental regulators/bottlenecks, green supply chains, climate warming impacts, energy saving methodologies, and integrated inventory/warehouse management will certainly reduce adverse environmental impacts. Ample thoughts are to be given at policy planning level, to ensure the adoption of innovative perceptions like greening the food supply chain, reducing greenhouse gas emissions during operation \& supply chain management, Incorporating environmental dimension in automated warehouses, applying environmentally sustainable solutions to take care of agricultural product loads and warehouse failures, inventory accuracy, location \& space utilization during warehouse layouts and commodity picking optimization. 


\section{International Advanced Research Journal in Science, Engineering and Technology}

Vol. 5, Issue 11, November 2018

\section{REFERENCES}

[1]. ASSOCHAM (2016). National Summit on Warehousing in India- technology options for Upgradation held on 26 th May, 2016 at India Habitat Centre, New Delhi

[2]. ASSOCHAM (2014), Press Trust of India, available online at http://articles.economictimes.indiatimes.com/2014-04-09/news/ 48999706_1 storage-capacity-warehousing-foodgrain

[3]. Birthal, P.S., Joshi, P.K. Negi, D.S. and Agarwal, S. (2014). Changing sources of growth in Indian agriculture." IFPRI discussion paper 01325. International food policy research institute, New Delhi.

[4]. Bathla, S. (2014). Public and private capital formation and agricultural growth: state-wise analysis of inter-linkages during pre-and post-reform periods. Agriculture Economics Research Review, Vol. 27(1).

[5]. Chand, Ramesh (2012). Development Policies and Agricultural Markets, Economic and Political Weekly, Vol-XLVII (52), India December 29, 2012

[6]. FCI (2018) available at http://fci.gov.in/storages.php, visited on 25.11.2018.

[7]. Fichtinger, J., J. M. Ries, E. H. Grosse, and P. Baker. 2015. "Assessing the environmental impact of integrated inventory and warehouse management." International Journal of Production Economics, Vol. 170 (Part C): 717-729.

[8]. Gaur, M. L. (2015). "Policies towards Warehousing \& Marketing- Chapter 24", In : India's Perspective Policy on Agriculture (Eds. M C Varshneya and Anil Javalekar), Pub : Uttan Krishi Sanshodhan Sanshtha \& Institute of Rural Development and Education, Pune, India, pp:199-205.

[9]. Govt of India (2011) : Report of the working group on warehousing development and regulation for The 12th plan period (2012-17), Planning Commission, Government of India, October 2011.

[10]. GOI, Planning Commission. (2013). "Twelfth Five Year Plan (2012/2017): Economic Sectors". Vol. II,. Government of India.

[11]. Gulati, A., and K. Ganguly. (2010). "The Changing Landscape of Indian Agriculture." Agricultural Economics Vol. 41(777): $37-45$.

[12]. Hazell, P. B. R., and Haggablade, S. (1991). Rural-urban growth linkages in India", Indian Journal of Agricultural Economics, Vol. 46 (4).

[13]. Meneghetti, A., and L. Monti. 2014. "Multiple-weight Unit Load Storage Assignment Strategies for Energy-efficient Automated Warehouses." International Journal of Logistics Research and Applications Vol. 17 (4): 304-322.

[14]. Meneghetti, A., and L. Monti. 2015. "Greening the Food Supply Chain: An Optimisation Model for Sustainable Design of Refrigerated Automated Warehouses." International Journal of Production Research Vol. 53 (21): 6567-6587.

[15]. Rai, D., B. Sodagar, R. Fieldson, and X. Hu. 2011. "Assessment of CO2 emissions reduction in a distribution warehouse." Energy Vol. 36 (4): 2271-2277.

[16]. Tappia, E., G. Marchet, M. Melacini, and S. Perotti. 2015. "Incorporating the Environmental Dimension in the Assessment of Automated Warehouses." Production Planning \& Control Vol. 26 (10): 824-838.

\section{BIOGRAPHIES}

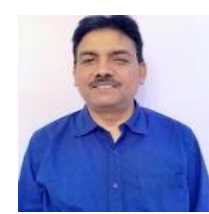

The lead author has more than 34 years multifarious experience in research, education and transfer of technology aspects of natural resources management, soil \& water conservation engineering, watershed planning and management, irrigation and drainage engineering, command area development \& management and many other portfolios of agricultural engineering sector. He obtained his $\mathrm{PhD}$ in the field of Hydrology from Indian Institute of Technology Roorkee and served for about 24 years holding various scientific positions at several National Research Institutions under Indian Council of Agricultural Research, New Delhi. Afterward he had been in agricultural education stream for last 10 years, holding positions of Professor, HOD, Principal, and also the Faculty Dean of Agricultural Engineering under his present organization i.e. Anand Agricultural University. He has more than 50 prime publications in international \& national journals and books with equal number of other publications in diverse fields of watershed, hydrology, grasslands, forest lands, rainfall runoff modeling, GIS\&RS, rainwater harvesting, soil erosion \& sedimentation, wasteland development and climate change/agrometeorological aspects. He has more than 6 national appreciations (medals, awards, fellowships) and several other professional recognitions in his name.

Second author, Ms. Shreya Gaur is an Environmental Engineering graduate from Governmental Engineering College Surat (Gujarat, India) who has about one year working experience in a prominent NRM based NGO namely 'Foundation for Ecological Security' (FES) under National Dairy Development Board (NDDB) Govt of India in Gujarat, and presently conducting her Masters in 'Civil \& Environmental Engineering' at University of Western Ontario, Canada. 